\title{
E-Commerce in Singapore and Indonesia: Comparison of Policies
}

\author{
Zang $\mathrm{Cao}^{1}$ \& Sahya Anggara ${ }^{2}$ \\ ${ }^{1}$ Asean Reseacrh, Singapore \\ Email: zang.cao@gmail.com \\ ${ }^{2}$ UIN Sunan Gunung Djati Bandung, Indonesia \\ Email: sahyaanggara@uinsgd.ac.id
}

\begin{abstract}
New media is a term that refers to products and services that provide information/entertainment using computers or the internet. The emergence of new media also encourages other activities that people usually do in a conventional way to the cyber world. Doing business is one example. Electronic commerce, or also known as e-commerce, is a trading method that uses the internet. Nowadays, e-commerce has become a trend in the world. Comprehensive regulations are needed to manage this activity. This paper will try to describe a comparative public policy on e-commerce in the two ASEAN countries, Singapore and Indonesia. We will see differences in e-commerce development in both countries, and attention to the role of governments as decision-makers in both countries.
\end{abstract}

Keywords: New Media, E-Commerce, Public Policy.

\section{A. INTRODUCTION}

New media is a term closely related to the emergence of means of communication through cyberspace. The Cambridge Dictionary defines new media as products and services that provide information or entertainment using computers/the internet. The presence of networks and the internet as new media makes it easier for the public to communicate and access information. The use of new media by the public is also increasingly diverse, one of which is to conduct buying and selling transactions. The system is called electronic commerce or electronic-commerce (e-commerce). The characteristics of new media that promise unlimited, fast, and interactive access make it easy for consumers to get a product as they wish. This opportunity is used by producers and distributors to market a product online.

The development of new media in the last decade has progressed throughout the world. With the rapid use of new media, the practice of e-commerce has increased. This has a significant influence on the economic development of countries, both macro, and micro. To support it, we need a tool that regulates the issue of using information technology in commerce in more depth. The UN International Trade Commission has formulated a policy model on e-commerce, which was later ratified by all its member states. Trade trends through electronic media also enter into discussions on the regional scope. In November 1999, organizations in the Southeast Asia region agreed on the e- 
ASEAN Task Force 3, a regulatory body consisting of representatives of the government and private parties from ten member countries. Among the objectives of establishing the e-ASEAN Task Force is to support the emergence of e-commerce in the form of dot-com businesses, and projects that support it, such as e-entrepreneurship seminars, ASEAN School Networks, regional trade networks, ASEAN World Master portals, and programs business / industry exchange (Orbeta, 2002: 133).

ASEAN countries such as Singapore, Malaysia, Thailand, the Philippines, and Indonesia have their policy formulations that regulate transactions through electronic media. Among these countries, Singapore, as a developed country in Southeast Asia, has the vision to become an International Electronic Commerce Hub, a country where all regional and international electronic trade transactions are processed. It's no wonder that Singapore has a comprehensive and adequate set of e-commerce activities. Meanwhile, with the provision of 237 million people, Indonesia is a Southeast Asian country that is projected to have promising prospects in the field of e-commerce. One indicator is through ad spending on the internet, whose growth has reached $200 \%$ from year to year. Unfortunately, the rules regarding e-commerce in Indonesia are not as complete and adequate as Singapore.

New media is emerging. Business people also use their use as a means of information and communication as a new tool in the realm of trade through e-commerce. The comparison of the policies of the two Southeast Asian countries, namely Indonesia and Singapore, in dealing with public issues related to interactions in e-commerce practices, is interesting to study in more depth. Three stages of policy comparison proposed by Richard Rose in the book Learning from Comparative Public Policy: A Practical Guide, namely Getting Started-Venturing Abroad-Returning Home, will be tried in this paper. Getting Started, by first understanding what new media and e-commerce are through a conceptual foundation, then Venturing Abroad, through an explanation of Singapore's vision as the Center for International E-Commerce and Returning Home, trying to see the issues surrounding E-Commerce in Indonesia.

E-commerce policies are essential for a country, as the rapid use of new media as a means of trade. For this reason, this paper will try to answer the question: How do ecommerce policies in Singapore and Indonesia compare?

\section{B. LITERATURE REVIEW}

\section{New Media}

New media is a new concept in the field of communication. However, according to Iowa State University for New Media, the use of this phrase turned out to have been used since the 1970s by researchers in the social, psychological, economic, political and cultural fields to define matters relating to information and communication technology. Since the emergence of CD-ROMs and the internet in the 1990s, the meaning of new 
media has grown from its original purpose. Until now, there are differences in interpreting new media.

Webopedia defines new media as a general term for different forms of electronic communication using computer technology. This term is the opposite of old media forms, such as print media such as newspapers and magazines. Webopedia classifies new types of media, namely: a) Web sites; b.) Streaming audio and video; c.) Chat rooms; d.) E-mail; d.) Online community; f.) Web advertising; g.) DVDs and CD-ROM media; h.) Virtual reality environments; i.) Integration of digital data with telephone data, such as Internet telephony; j.) Digital cameras; and k.) Mobile computing. The use of new media indirectly refers to data communication that takes place between desktop and laptop computers and handheld computers such as PDAs and media originating from CDs or floppy disks.

Whereas PC Magazine Encyclopedia has two definitions of new media:

a. The forms of communicating in the digital world, which include publishing on CDs, DVDs, and, most significantly, over the Internet. It implies that the user obtains the material via desktop and laptop computers, smartphones, and tablets. Every company in the developed world is involved with new media. Contrast with old media.

b. The concept that new methods of communicating in the digital world allow smaller groups of people to congregate online and share, sell and swap goods and information. It also allows more people to have a voice in their community and the world in general.

In essence, the phrase new media is closely related to the development of information technology. The concept of new media used in this paper refers more to the emergence of interconnection networks as new media. The presence of the internet brought the world into the digital age. Interactions that are usually done conventionally in the real world, such as interactions in trading activities, can now be done in cyberspace.

\section{Electronic Commerce}

Electronic commerce (e-commerce) is one of the activities carried out using new media. This system has changed the way consumers get a product they want. According to M. Pattinson, "There are several features, which distinguish electronic commerce from business conducted by traditional means. In particular: electronic commerce establishes a global market place, where conventional geographic boundaries are not ignored; they are entirely utterly irrelevant (Mansur \& Gultom, 2005: 145).

Transactions in e-commerce are grouped into two major parts, namely: business to business / b to b, and business to consumer / b to c (Maghfirah, 2004: 3). The practice 
of $b$ to $b$ is carried out between business people, while $b$ to $c$ takes place between business people and their consumers. Things that need to be considered in the implementation of e-commerce is the need for a policy that is not only oriented to the aspects of security, certainty, and convenience of consumers in the transaction, but also able to eliminate various obstacles in trade (Mansur \& Gultom, 2005: 147).

Trade has a positive impact on a country's economy. Therefore optimizing the role of new media in business must be supported by the formation, formulation, and implementation of appropriate policies by all parties involved in it.

\section{RESUlt AND DISCUSSION}

\section{Vision of Singapore as an International E-Commerce Center}

Discourse about new media has been present since the advent of computers in the 1980s. However, the term new media began to bloom since the public was familiar with the internet and used it. Many countries are not ready for regulations related to the use of new media. Singapore is a country that is responsive to the development of new media. Being an international e-commerce center is one of the goals that must be achieved to realize Singapore's big goal as a center for global IT production and use. This vision was not immediately announced. Singapore has designed a strategy even since the inception of the new media in 1980. Its implementation is divided into four phases. The initial step was in 1980-1985, by first establishing a computerized government system. The second phase was carried out in 1986-1990, by striving to make computerization and access to information accessible to the national community so that in the third phase throughout 1990-1999, Singapore could become an 'Intelligent' Island and IT center. Entering 2000, Singapore reached the fourth phase by building its country into a Global IT Center.

Singapore made an extraordinary effort in carrying out its strategy. The implementation begins with implementing the use of information technology (IT) in industry, government, and universities (Heng, 2002: 147-148). In the third phase, Singapore began to design policy formulations governing the use of new media. In 1993, the Computer Misuse Act (CMA) policy was included in Chapter 50 A of the Singapore Constitution. CMA is the adoption of a policy from the 1990 British law regarding misuse in computer use. This law has been revised at least four times, and the last amendment was made in 2005.

Meanwhile, policies explicitly relating to trading activities through electronic media were introduced in 1996 through the E-Commerce Hotbed Program (Wong, 2003: 
26). The first official regulation regarding e-commerce in Singapore contains infrastructure in developing e-commerce, both legally and technically. In 1998, a more comprehensive law was issued by the Singapore government, namely the Electronic commerce Master Plan. The vision of Singapore as an International E-Commerce Center began to be announced in the Master Plan. The realization plan is pursued by building strength in international trade, international financial services, and telecommunications, and transportation infrastructure. The Master Plan also aims to create e-commerce as a service industry by attracting foreign investment in e-commerce activities, accelerating electronic shipping services as a public service, encouraging companies to use ecommerce services, and harmonizing laws and e-commerce policies.

Laws and policies related to e-commerce are the responsibility of the National Computer Board (NCB), which is under the auspices of the Ministry of Trade and Industry (Ministry of Trade and Industry / MTI) of Singapore. NCB was established in 1981, following Singapore's strategy in mastering IT in 1980. In 1999, NCB was merged with the Telecommunications Authority of Singapore (TAS), which was established in 1992 as a telephone service provider in Singapore (Daniel, 2002: 2). The process of merging the two bodies gave birth to the Info-communications Development Authority (IDA) under the auspices of the Ministry of Communications and IT (Ministry of Communications and IT / MCIT) (Daniel, 2002: 4). In 2001, MCIT expanded its scope of responsibility to regulate the world of broadcasting and content on the internet, so that its name changed to the Ministry of Information, Communications and the Arts (MITA).

Electronic Transaction Law, Intellectual Property Rights, Rules on Evidence of Transactions, Regulation of New Media Content, Tax Issues, and Export and Import Procedures are basic rules and technical infrastructures that support the security and realization of e-commerce. The Singapore Electronic Transaction Act, the Electronic Transaction Act, was passed on July 10, 1998. The law aims to regulate all forms of electronic communication facilities. Recognition of Intellectual Property Rights came into force in Singapore after the country approved the Berne Convention for the Protection of Literary and Art Works in September 1998. Furthermore, the issue of copyright is regulated in the Copyright Act of 1999. In 1997 an amendment to the Evidence Act was carried out, which also governs evidence in electronic transactions. The government also issued several licenses and codes of conduct governing content in electronic media, such as the SBA (Class License) Notification issued on July 15, 1996, and the SBA Internet Code of Practice, which came into force on November 1, 1997. Tax issues in e- 
activities commerce are also regulated by the Singapore Inland Revenue Authority (IRAS) 6, while export and import matters are handled by the Singapore Trade Development Board (TDB) 7.

\section{The Development of E-Commerce in Indonesia}

In Indonesia, the e-commerce phenomenon has been known since 1996 through the emergence of http://www.sanur.com. The site is the first online bookstore in Indonesia (Mansur \& Gultom, 2005: 144). Then, several e-commerce services began to appear. Sites like astaga.com, mandirionline.com, and satunet.com were popular. However, the monetary crisis that struck Indonesia around 1998 worsened the progress of the ecommerce business. Lately, the development of e-commerce has again caught the attention. Because of the high level of visits, social networking has become one of the main bases of e-commerce activities in Indonesia. Indonesian people make social networks like Facebook and Twitter to market products. More than half of the members of kaskus.com, totaling 3,047,0398, used the community network to buy and sell. So, in addition to sites that purely provide e-commerce services such as plasa.com, tokobagus.com, or tokopedia.com, several e-commerce service provider sites eventually combine the concept of online commerce with social networking systems. For example, the online bookstore bukukita.com, not only sells books but also facilitates its members to meet in person. Some e-commerce services insert other content variations in addition to product offerings, such as krazymarket.com, which also features news on its site. Until 2011, according to a survey conducted by the Ministry of Communication and Information, as many as $24 \%$ of Indonesia's population made purchases through ecommerce.

The increasing volume of trade through electronic media in Indonesia is not without obstacles. Some problems, such as inequality of internet access in Java and outside Java, faulty cable, and wireless network infrastructure, are technical obstacles in business through e-commerce. In general, there are five other factors that hinder the sustainability of e-commerce activities in Indonesia in addition to access and infrastructure, namely public awareness, security in transactions, limited internet banking facilities, culture or habits in Indonesia that are not familiar with the use of new media in the field of trade, and barriers from e-commerce providers that do not fully have credibility and can be trusted (Onti-Rug, 2008).

These obstacles should be managed through an adequate set of policies. While 
there is no comprehensive policy regarding e-commerce in Indonesia, some general rules related to trade and the use of information technology can be used as a guide for Indonesian citizens in running e-commerce. For example, Law No. 8 of 1997 concerning Company Documents, which slightly touches on electronic data verification, Law No.36 of 1999 concerning Telecommunications, Law No. 19 of 2002 concerning Copyright, as well as several articles in the Criminal and Civil Code. In the Criminal Code, Article 362 of the Criminal Code can be used to trap perpetrators of carding, namely the theft of credit card numbers to conduct e-commerce transactions. Also, article 378 of the Criminal Code can be applied to fraudsters in e-commerce activities, for example, for those who display advertisements on the website so that it attracts visitors to buy the goods and transfer some money. Still, in reality, the ordered products do not come. Whereas in the Civil Code, there is article 1233 of the Civil Code concerning the binding agreement that can be used in the sale and purchase agreement and section 1338 of the Civil Code which states that the Indonesian treaty law adheres to the principle of freedom of contract so that the validity of the trade agreement is returned to all parties involved in the transaction.

Traditional e-commerce and buying and selling activities have very different characteristics, so that comprehensive rules regarding e-commerce in Indonesia are necessary. The existing law does not yet exist specifically regulating the basic rules and technical infrastructures that support the security and realization of e-commerce in Indonesia. The presence of Law No.11 of 2008 regarding Electronic Information and Transactions was initially expected to be able to answer all public issues related to the development of IT in Indonesia. In Chapter V of the Act, electronic transactions are explicitly discussed, namely from article 17-article 22. But in reality, the law is not sufficient to be used as a legal umbrella in automated transaction activities, especially ecommerce.

Plans regarding the development of information and communication technology in Indonesia are included in the Master Plan for the Acceleration and Expansion of Indonesian Economic Development (MP3EI) launched by the Indonesian government in 2011. Responsibility for the law and policy regarding information and communication technology falls under the auspices of the Department of Communication and Information. But until now, a body that handles explicitly issues surrounding e-commerce activities in Indonesia has not yet been formed. 


\section{Comparison of E-Commerce Policies in Singapore and Indonesia}

Singapore has had a vision to become an International E-Commerce Center since 1998 through the E-Commerce Master Plan. The idea is the fourth phase listed in the strategy made by Singapore to develop information and communication technology in 1980 while the development of information and communication technology in Indonesia was only mentioned in the Master Plan for the Acceleration and Expansion of Indonesian Economic Development (MP3EI) which was launched in 2011. According to Heidenheimer, "Comparative public policy is the study of how and why different governments do or do not do an action and what effect it has, in the comparison of public policies regarding e-Commerce.

E-commerce in Singapore and Indonesia, 'how and why the Singapore government is preparing such a mature policy set on e-commerce,' or 'how and why the Indonesian government has not made a complete and adequate policy like in Singapore' will try to be analyzed through a common approach -economics.

Singapore is a vibrant and developed country in Southeast Asia. The country has advantages in the fields of transportation, education, and finance. The excellence in the socio-economic field is the capital for Singapore to take a leading role in technology, including in the use of new media as a means of trade. The country's infrastructure readiness also supports Singapore's preparation for e-commerce policies.

Unlike the case with Indonesia. From the social side, Indonesia, before the reform, was a quasi-democratic country. The Indonesian government is acting authoritarian. Access to information for the wider community is difficult and limited. Therefore, at that time, the development of new media was not heard echoing in Indonesia. The 1998 reforms finally opened the door to freedom of expression and information disclosure. Unfortunately, along with the fall of the dictatorial regime, the monetary crisis hit Indonesia. There are so many things that need to be addressed by the Indonesian government, especially in economic matters, so that the problem of the development of information and communication technology is not included in the priority of the policy agenda.

The Indonesian government's concern about the development of new media and its use has only been seen lately. This change in attitude was driven by a large number of Indonesians becoming internet service users and then using it for various things such 
as trade. E-commerce services established by private parties have sprung up. New media is becoming a public consumption, but the rules of the game regarding their use have not been sufficient to cause problems. The drafting of Lawson Information and Electronic Transactions is based more on community needs rather than government initiatives. If the push for public needs is more instrumental in making policy in Indonesia, the readiness and motivation of the government to advance the country is more clearly seen as a driving factor for the issuance of e-commerce policies in Singapore. Socially, Singaporeans are accustomed to obeying government regulations, which, despite being authoritarian, are serious about seeking economic prosperity for their residents. Efforts to excel in the field of technology began among the bureaucracy. The government is pursuing a computerized government system. After that, they have then built a tech-literate society.

Policy in Indonesia is a form of community participation, while the system in Singapore is an elite product. Thus, the policymaking process in Indonesia can be interpreted as a pluralist policy model, while policies in Singapore are classified as elitist policies. Beyond the applicable policy model, a comparison of policies regarding ecommerce in Singapore and Indonesia can be seen through the factors driving the emergence of systems. In theory, policy arises due to public problems. But the development of a plan is more due to the government's responsiveness in responding to the phenomena that occur. Even if a general question is raised, an unresponsive government will not be able to return to the problem (then put it on the policy agenda and formulate a policy).

The effect of comparison of policies regarding e-commerce in Singapore and Indonesia, of course, can be seen from the achievements of the two countries in the use of new media through e-commerce services. Indonesia is far behind Singapore. Thanks to precise planning and regulations, sales figures through e-commerce services in Singapore reached $1.23 \%$ of the gross domestic product in the country in 2000 . This will increase from year to year. Indonesia can become an international e-commerce center. Indonesian people's participation in the use of new media must be maintained, while the concern of the Indonesian government as a policymaker needs to be increased.

There are still many other socio-economic variables that influence the comparison of e-commerce policies between Singapore and Indonesia. This factor does not only come from the government. Society and government influence each other, for example, in terms of the availability of internet facilities. On the one hand, the Indonesian gov- 
ernment is indeed not serious in handling the problem of equitable access to information. However, the level of economy and education of Indonesian people is still low, so that they do not pay too much attention to the development of new media. Although the number of internet users is increasing and the progress of e-commerce services is increasingly visible. Still, the number is only a percentage of the middle class in Indonesia. This is why the government is not overly concerned about e-commerce problems in Indonesia.

\section{CONCLUSION}

The development of new media presents a new way of doing commerce, namely, e-commerce. E-commerce activities began to be practiced in countries around the world, including Singapore and Indonesia. However, there are differences in the policies adopted by the two countries. The Singaporean government is far better equipped in all matters in dealing with e-commerce issues because it has had a strategic plan regarding the use of information and communication technology since three decades ago, while the Indonesian government is just concerned about the importance of the use of information and communication technology recently.

Comparative public policy is the study of how and why different governments do or don't take action and what its effects are. When compared, the Singapore government's decision to do careful planning regarding the use of technology since the 1980s with the Indonesian government's new ratification of the Information and Electronic Transaction Law in 2008 is closely related to socio-economic factors. These factors ultimately affect the responsiveness of the government to provide appropriate regulation of a public problem. In effect, a country that plans and implements policies completely and adequately will be far superior to a country whose governments are unresponsive to their obligations as policymakers.

Public policy is not just a formulation of the answer to a general problem. Moreover, public policy will have far more impact if it is formulated before many open issues related to a phenomenon in line to be resolved. In this case, the government is demanded to be responsive to the surroundings. As Robert Eyestone said, public policy is a relationship of a unit (government) with its environment. 


\section{REFERENCES}

1. Dunn, W. N. (2003). Public Policy Analysis: An Introduction to the 2nd Edition, the Indonesian edition Introduction to Public Policy Analysis Second Edition. Yogyakarta: Gadjah Mada University Press.

2. Mansur, D. M. A., \& E. Gultom, (2005). Cyber Law: Legal Aspects of Information Technology. Bandung: Refika Aditama.

3. Michael, E. J. (2006). Public Policy: The Competitive Framework. New York: Oxford.

4. Parsons, W. (2006). Public Policy: An Introduction to the Theory and Practice of Policy Analysis, the Indonesian edition of Public Policy: Introduction to Policy Analysis Theory and Practice. Jakarta: Prenada Media.

5. Rose, R. (2005). Learning from Comparative Public Policy. New York: Routledge.

6. Winarno, B. (2007). Public Policy: Theory and Process. Yogyakarta: Media Pressindo.

7. Heng, T. M. (2002). Singapore as a Regional Information Technology Hub,' in C. S. Yue and J. J. Lim (ed.), Information Technology in Asia: New Development Paradigm, Singapore: Institute of Southeast Asian Studies.

8. Orbeta J. R. (2002). E-Commerce in Southeast Asia: A Review of Developments, Challenges, and Issues, in CS Yue and JJ Lim (ed.), Information Technology in Asia: New Development Paradigm, Singapore: Institute of Southeast Asian Studies.

9. Damayanti, D. (2011). Online Media Competition: Towards Multiplatform and Convergence. Kompas, 17 June 2011, p.35.

10. DOT/HAR/GUN/NMP. (2011). Emerging Business Entrepreneurs on the Internet, Kompas, June 17, 2011.

11. Golose, P. R. (2008). Cybercrime Developments and Handling Efforts in Indonesia by the National Police. Bulletin of Banking and Banking Law, 4(2).

12. Pambudy, N. M. (2011). Business on the Internet: Still Green but Increasingly Steady. Kompas, 17 June 2011, p.33.

13. Urbas, G. (2008). An Overview of Cybercrime Legislation and Cases in Singapore. Asian Law Institute Working Paper Series No. 001, Australia, December 2008.

14. Daniel, S. K. B. (2002). The Impact of the Regulatory Framework on E-Commerce in Singapore. Singapore: Singapore Academy of Law.

15. E. D. Maghfirah. (2011). Consumer Protection in E-Commerce, http://www.solusihukum.com/artikel/artikel31.php, Accessed June 19, 2011. 
16. IDA. (2010). Electronic Transactions Act, Singapore: Info-communications Development Authority http://www.ida.gov.sg/Policies\%20and\%20Regulation/20060420164343.aspx. $\quad$ Accessed June 19, 2011.

17. Iowa State University Studio for New Media. (2011). What Does New Media Mean? (online), http://newmedia.engl.iastate.edu/about/what is new media, accessed on 19 June 2011.

18. L. D. Harsono. (2011). E-Commerce Law, Security and Cyber Law, http://prothelon.com/imtelkom/7.\%20cyberlaw\%20bw.pdf, accessed June 20, 2011.

19. Onti-Rug. (2008). Online Trade Agreement, http://www.lawskripsi.com/index.php?option=com content\&view=article\&id=11\&Ie $\underline{\text { mid=11, Accessed June 19, } 2011 .}$

20. PC Magazine Encyclopedia, New Media Definition from PC Magazine Encyclopedia (online), http://www.pcmag.com/encyclopedia term/0,2542,tnew+media\&i=47936,00.asp, Accessed June 18, 2011.

21. P. K. Wong. (2003). Global and National Factors Affecting E-Commerce Diffusion in Singapore. Singapore: Taylor and Francais Group.

22. Staff Attorney. (2008). Internet Law-Fighting Computer Crime in Singapore (online), http://www.crime-research.org/news/01.04.2008/3286/, accessed on 19 June 2011.

23. Webopedia, What is New Media? (online), http://www.webopedia.com/TERM/N/new media.html, accessed June 18, 2011. 